\section{Jefferson}

Thomas Jefferson University

HOME OF SIDNEY KIMMEL MEDICAL COLLEGE

Collaborative Healthcare: Interprofessional Practice, Education and Evaluation (JCIPE)

January 2011

\title{
From the Editors
}

Molly A. Rose, RN, PhD

Thomas Jefferson University, molly.rose@jefferson.edu

Christine A. Arenson, MD

Thomas Jefferson University, christine.arenson@jefferson.edu

Follow this and additional works at: https://jdc.jefferson.edu/jcipe

Part of the Medicine and Health Sciences Commons

Let us know how access to this document benefits you

\section{Recommended Citation}

Rose, RN, PhD, Molly A. and Arenson, MD, Christine A. (2011) "From the Editors," Collaborative Healthcare: Interprofessional Practice, Education and Evaluation (JCIPE): Vol. 3 : Iss. 1 , Article 1.

Available at: https://jdc.jefferson.edu/jcipe/vol3/iss1/1

This Article is brought to you for free and open access by the Jefferson Digital Commons. The Jefferson Digital Commons is a service of Thomas Jefferson University's Center for Teaching and Learning (CTL). The Commons is a showcase for Jefferson books and journals, peer-reviewed scholarly publications, unique historical collections from the University archives, and teaching tools. The Jefferson Digital Commons allows researchers and interested readers anywhere in the world to learn about and keep up to date with Jefferson scholarship. This article has been accepted for inclusion in Collaborative Healthcare: Interprofessional Practice, Education and Evaluation (JCIPE) by an authorized administrator of the Jefferson Digital Commons. For more information, please contact: JeffersonDigitalCommons@jefferson.edu. 


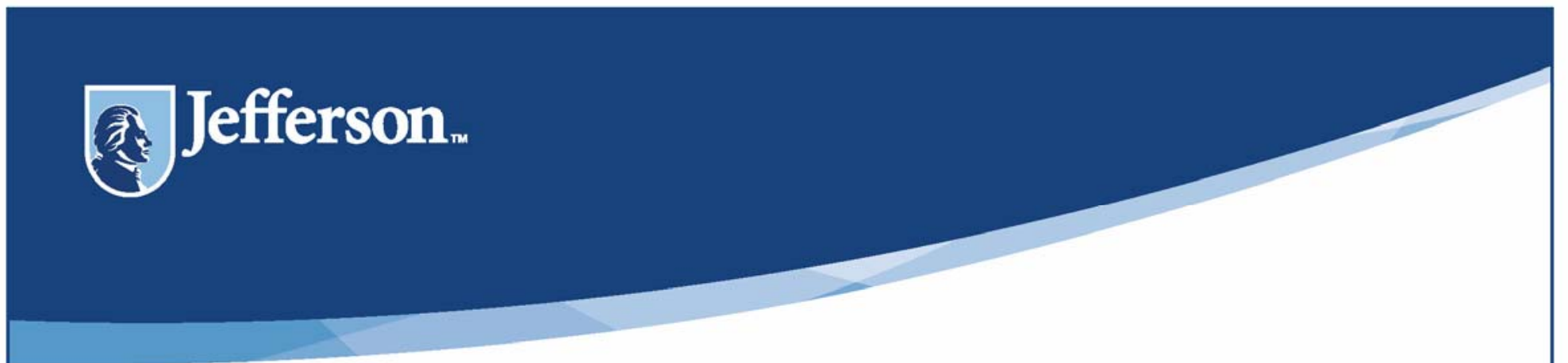

\section{Interprofessional Education and Care Newsletter}

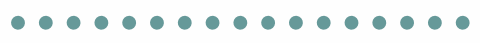

Summer 2011

Inside this issue:

Selected Interprofessional

Activities at the University

Clinical Skills \& Simulation

Center

2

Providing for the Medical and Social Needs of Newly

Resettled Refugees in Philadelphia

3

Evaluation of IPE Programs: Developing a Tool to Assess Students' Attitudes toward Chronic Illness 4-5

Announcements 5-6

Upcoming Faculty and Staff Development Programs 6-7

\section{From the Editors}

Welcome to the latest edition of the Jefferson Interprofessional Education and Care Newsletter. We are pleased to describe the launch of two reports essential to interprofessional education and practice in the United States that occurred on May 11, 2011: Core Competencies for Interprofessional Collaborative Practice and Team-Based Competencies, Building a Shared Foundation for Education and Clinical Practice. The first report, Core Competencies for Interprofessional Collaborative Practice, was produced by an expert panel convened in 2009 by the Interprofessional Education Collaborative (IPEC), a unique partnership of six associations the American Association of Colleges of Nursing, the American Association of Colleges of Osteopathic Medicine, the American Association of Colleges of Pharmacy, the American Dental Education Association, the Association of American Medical Colleges, and the Association of Schools of Public Health. The panel proposed four domains of core competencies needed to provide integrated, collaborative, high-quality, cost-effective care to patients within the nation's current, evolving health care system. The four domains are values and ethics of interprofessional practice, leverage of the unique roles and responsibilities of interprofessional partners, communication with patients, families, communities and other health professionals, and team based care to deliver patient/population-centered care that is safe, timely, efficient, effective, and equitable. The panel also identified 38 specific sub-competencies that describe the essential behaviors across the four domains. We are thrilled to report that Jefferson's Health Mentors Program was cited in the report as an exemplar of interprofessional learning activities. The second report, Team-Based Competencies, Building a Shared Foundation for Education and Clinical Practice, was the result of a conference sponsored by the Health Resources and Services Administration, the Josiah Macy Jr. Foundation, the Robert Wood Johnson Foundation, and the ABIM Foundation in partnership with IPEC. The meeting, held in February 2011, brought together more than 80 leaders from various health professions to preview the core competencies presented by IPEC, and create action strategies that would use them to "transform health professional education and health care delivery in the United States." Recommended action strategies include dissemination of the core competencies to key stakeholders - academic deans, policymakers, and health care leaders; launch of an education campaign that makes the critical link between collaborative health care teams and providing high-quality, safe, and cost-sensitive treatment; preparation of faculty for teaching students how to work effectively as part of an interprofessional team; development of metrics for interprofessional education and collaborative care to help advance team-based competencies in teaching and practice; and forging partnerships among the academic community, health care providers, and government agencies to advance interprofessional education. The articles within this newsletter are examples of interprofessional activities that clearly fall within the newly developed U.S. core competencies.

Molly A. Rose, RN, PhD

Christine A. Arenson, MD

Editors 